\title{
Effect of Canopy of Acacia nilotica on Soil Fertility Status at Varying Soil Depths in Wheat Based Agroforestry System
}

\author{
Chatar Singh $^{1 *}$ and Shayma Parveen ${ }^{2}$ \\ ${ }^{1}$ College of forestry Ranichauri, Tehri Garhwal Uttarakhand, India \\ ${ }^{2}$ Institute of Agricultural Sciences Bundelkhand University Jhansi (UP), India \\ *Corresponding author
}

\begin{tabular}{|c|c|}
\hline & A B S T R A C T \\
\hline $\begin{array}{l}\text { Canopy, } \\
\text { Acacia nilotica, } \\
\text { Soil fertility }\end{array}$ & \multirow{3}{*}{$\begin{array}{l}\text { In the present study, a considerable build up in soil organic carbon under tree } \\
\text { canopy as compared to open canopy was found and soil organic carbon under tree } \\
\text { canopy decreased with an increase in soil depth and increasing canopy distance. } \\
\text { The total nitrogen percentage in soil decreased with an increase in depth and } \\
\text { canopy. In case of available soil phosphorus, it decreased under the tree canopy } \\
\text { with increasing soil depth and canopy distance. The value of available soil } \\
\text { phosphorus as well as potassium was found higher under the canopy and available } \\
\text { potassium in soil was found higher than the open canopy. However, it was found } \\
\text { decreasing towards the depth and canopy. The plantation of Acacia nilotica in } \\
\text { cropland brought a reduction of soil pH. Therefore a reduction in availability of } \\
\text { nutrients under tree canopy was noticed outwards the canopy. }\end{array}$} \\
\hline Article Info & \\
\hline $\begin{array}{l}\text { Accepted: } \\
15 \text { September } 2020 \\
\text { Available Online: } \\
10 \text { October } 2020\end{array}$ & \\
\hline
\end{tabular}

\section{Introduction}

Acacia nilotica commonly known as Babul, Kikar or Indian gum Arabic tree has been recognized worldwide as a multipurpose tree. It is widelly distributed throughout arid and semiarid zones of the world. It can play a crucial role to improvement of degraded soil through nitrogen fixing ability. Soil is the uppermost fertile layer of the earth crust and provides base for anchoring of plants and crops. It is one of the most important natural resources which are adversely suffering from the removal of tree cover. Most of the soils are infertile and cannot support sustainable production. Even some soils which were once fertile are now depleted of nutrients and can no longer sustain production. If this precious resource does not get protection, its fertility and productivity will decline and it will become difficult to sustain the human and animal population even its present level. Enhancement and maintenance of soil fertility and productivity are essential for the sustainability of agriculture to meet the basic food needs of the increasing population of India. Maintenance and enhancement of soil fertility are vital for global food security and environmental sustainability (Rosegrant and Cline, 2003, Stocking, 2003). Maintaining 
and enhancing the soil fertility of farmlands to grow food grains, as well as tree biomass, can help meet the demand in the future. Treebased agro-ecosystems have more closed nutrient cycles that help conserve soil productivity. Planting and pruning $\mathrm{N}$-fixing legumes is a feasible way to add Nitrogen to the systems (Mc-Grath et al., 2000). As climate change progresses, the effect of elevated $\mathrm{CO}_{2}$ itself will have a positive effect on the growth and nitrogen fixation of several Australian Acacia species (Schortemeyer, 2002) that grow very well in India. Agriculturally induced succession pathways often lead to dominance by leguminous trees and therefore serve as a mechanism for increasing $\mathrm{N}$ oxide emissions from tropical regions (Erickson, 2002). In regions where the green revolution has not been able to make dent due to lack of soil fertility agroforestry may hold promise (Sanchez 2000, 2002).

The present study was carried out examine how soil properties vary under the canopy of Acacia nilotica with varying canopy and soil depth. It was hypothesized that the plantation of Acacia nilotica at the farmer's field over the years improved soil fertility.

\section{Materials and Methods}

The study was carried out at an established field at Gwalior district in Bundelkhand region. The site is located in the semi-arid transitional zone of the central India characterized by undulating topography, variable soil and subtropical climate with low to very high (above $45^{\circ} \mathrm{C}$ ) temperature. In this study, the soil sampling scheme consisted of four canopy viz. $\mathrm{C}_{1}$ (25\% of canopy), $\mathrm{C}_{2}$ (50 $\%$ of canopy), $\mathrm{C}_{3}$ (75\% of canopy) and $\mathrm{C}_{4}$ (100\% of canopy), and three soil depths viz. 0-10 cm $\left(D_{1}\right), 11-20 \mathrm{crn}\left(\mathrm{D}_{2}\right)$, and $20-30 \mathrm{~cm}$ $\left(\mathrm{D}_{3}\right)$ under canopy of $A$. nilotica. Wheat was taken as an intercrop. Each sample was replicated three times. Thus, 36 soil samples were drawn for the investigation. Each soil sample soil so augured was mixed thoroughly and collected about $500 \mathrm{gm}$ soil in labeled polybags by quartering. Soil samples were brought into the laboratory and spread for air dry in the shade. After air drying, soil samples were ground and passed through $2 \mathrm{~mm}$ sieve. A portion of the $2 \mathrm{~mm}$ sieved soil was further sieved through a $0.2 \mathrm{~mm}$ sieve for the estimation of soil organic carbon. Soil $\mathrm{pH}$ was determined by electronic method with Systronic pH meter model 322-1 glass electrode assembly in 1: 2.5 soil-water suspension (Richards, 1954). Organic carbon in the soil was estimated by Walkley and Black, (1934) method. This method involved oxidation of organic matter with chromic acid and the excess potassium dichromate was back titrated against ferrous ammonium sulphate. Total nitrogen was calculated from the approximation Jackson, (1971). Available phosphorus was determined colorimetrically by extracting the soil with $\mathrm{O} .5 \mathrm{~N} \mathrm{NaHC03}$ at $\mathrm{pH}$ 8.5. Olsen et al., (1954) and measuring the intensity of blue colour developed by ammonium molybdate stannous chloride. Available $\mathrm{K}$ in soil was determined by extracting the soil with IN neutral ammonium acetate Metson, (1956) and measured the concentration in the filtrate using a flame photometer. The effect of Acacia nilotica on soil variable was tested employing ANOVA using the Factorial experiment. Thereafter, by calculating the critical difference at 5\% probability significance of treatment means were tested.

\section{Results and Discussion}

The data given in (Table 1) showed that the effect of A. nilotica on soil $\mathrm{pH}$ was found to be non-significant. Under the $\mathrm{C}_{4}$ canopy of $A$. nilotica, the highest value (8.30) soil was observed at $\mathrm{D}_{2}$ depth and the maximum mean value of soil $\mathrm{pH}$ was recorded 8.33 under $\mathrm{C}_{4}$ 
canopy whereas the mean soil $\mathrm{pH}$ was highest (8.23) at $\mathrm{D}_{3}$ soil depth. Across the canopy, the mean soil $\mathrm{pH}$ increased with increased in soil depth. However, the highest value of soil $\mathrm{pH}$ (8.33) was recorded under tree canopy at $\mathrm{D}_{3}$ soil depth and $\mathrm{C}_{4}$ canopy while the soil organic carbon at $\mathrm{D}_{1}$ soil depth and $\mathrm{C}_{1}$ canopy was found lowest (8.03). The results revealed that, under the canopy of $A$. nilotica decreases the soil $\mathrm{pH}$ decreased. The lowering of $\mathrm{pH}$ under tree canopy can also be explained on the basis that organic acids were produced during the decomposition of organic matter. Lowering of $\mathrm{pH}$ in agroforestry system were also reported by Parthiban and Rai (1994)

The results depicted showed in (Table 2), that soil depth and the canopy of A.nilotica, affected the mean organic carbon \% in soil, significantly. Irrespective of soil depth the mean soil organic carbon (0.5 $6 \%$ ) was found significantly higher at $\mathrm{C} 1$ canopy. The value of mean soil organic carbon was recorded highest $0.56 \%$ in $\mathrm{C}_{1}$ canopy whereas the mean soil organic carbon was highest $(0.52 \%)$ at $\mathrm{D}_{1}$ soil depth in comparison to $\mathrm{D}_{2} \& \mathrm{D}_{3}$ soil depth. Across the canopy, the mean soil organic carbon decreased with increase in soil depth.

The mean soil organic carbon at a reduction in the availability of organic carbon in soil under this tree was observed outwards the canopy. However, the highest value of soil organic carbon percentage $(0.67 \%)$ was recorded under tree canopy at $\mathrm{D}_{1}$ soil depth and $\mathrm{C}_{1}$ canopy while the soil organic carbon at $\mathrm{D}_{3}$ soil depth under $\mathrm{C}_{4}$ canopy was found lowest $(0.37 \%)$. The availability of organic carbon in soil under its canopy was found significant. The higher amount of organic carbon in soil under tree canopy could be explained from the fact that the major avenue for the addition of organic matter from the tree to the soil in the form of litter fall Singh et al., (2004).

Table.1 Soil $\mathrm{pH}$ under the canopy of A. nilotica at different soil depth

\begin{tabular}{|c|c|c|c|c|c|}
\hline \multirow[t]{2}{*}{ Soil Depth } & \multicolumn{4}{|c|}{ Canopy } & \multirow[t]{2}{*}{ Mean } \\
\hline & $\mathbf{C}_{1}$ & $\mathbf{C}_{2}$ & $\mathrm{C}_{3}$ & $\mathrm{C}_{4}$ & \\
\hline $\mathbf{D}_{1}$ & 8.03 & 8.10 & 8.17 & 8.26 & 8.14 \\
\hline $\mathbf{D}_{2}$ & 8.07 & 8.20 & 8.20 & 8.30 & 8.19 \\
\hline $\mathbf{D}_{3}$ & 8.10 & 8.23 & 8.27 & 8.33 & 8.23 \\
\hline Mean & 8.07 & 8.18 & 8.21 & 8.30 & \\
\hline C.D. $(5 \%)$ & $\mathrm{C}=\mathrm{NS}$ & $\mathrm{D}=\mathrm{NS}$ & $C * D=N S$ & & \\
\hline
\end{tabular}

Table.2 Organic carbon \% in Soil under the canopy of A. nilotica at different soil depth

\begin{tabular}{|c|c|c|c|c|c|}
\hline \multirow{2}{*}{ Soil Depth } & \multicolumn{4}{|c|}{ Canopy } & \multirow{2}{*}{ Mean } \\
\cline { 2 - 5 } & $\mathbf{C}_{\mathbf{1}}$ & $\mathbf{C}_{\mathbf{2}}$ & $\mathbf{C}_{\mathbf{3}}$ & $\mathbf{C}_{\mathbf{4}}$ & \\
\hline $\mathbf{D}_{\mathbf{1}}$ & 0.67 & 0.51 & 0.47 & 0.44 & $\mathbf{0 . 5 2}$ \\
\hline $\mathbf{D}_{\mathbf{2}}$ & 0.57 & 0.45 & 0.44 & 0.41 & $\mathbf{0 . 4 7}$ \\
\hline $\mathbf{D}_{\mathbf{3}}$ & 0.43 & 0.42 & 0.38 & 0.37 & $\mathbf{0 . 4 0}$ \\
\hline Mean & $\mathbf{0 . 5 6}$ & $\mathbf{0 . 4 6}$ & $\mathbf{0 . 4 3}$ & $\mathbf{0 . 4 1}$ & \\
\hline C.D. (5\%) & $\mathbf{C}=$ & $\mathbf{D}=$ & $\mathbf{C} * \mathbf{D}=\mathbf{N S}$ & & \\
\hline
\end{tabular}


Table.3 Total Nitrogen \% in Soil under the canopy of A. nilotica at different soil depth

\begin{tabular}{|c|c|c|c|c|c|}
\hline Soil Depth & \multicolumn{4}{|c|}{ Canopy } & Mean \\
\cline { 2 - 6 } & $\mathbf{C}_{\mathbf{1}}$ & $\mathbf{C}_{\mathbf{2}}$ & $\mathbf{C}_{\mathbf{3}}$ & $\mathbf{C}_{\mathbf{4}}$ & \\
\hline $\mathbf{D}_{\mathbf{1}}$ & 0.058 & 0.044 & 0.039 & 0.038 & $\mathbf{0 . 0 4 4}$ \\
\hline $\mathbf{D}_{\mathbf{2}}$ & 0.049 & 0.039 & 0.038 & 0.035 & $\mathbf{0 . 0 4}$ \\
\hline $\mathbf{D}_{\mathbf{3}}$ & 0.037 & 0.036 & 0.032 & 0.031 & $\mathbf{0 . 0 3 4}$ \\
\hline Mean & $\mathbf{0 . 0 4 8}$ & $\mathbf{0 . 0 3 9}$ & $\mathbf{0 . 0 3 6}$ & $\mathbf{0 . 0 3 5}$ & \\
\hline C.D. (5\%) & $\mathbf{C}=$ & $\mathbf{D =}$ & $\mathbf{C} * \mathbf{D}=$ & & \\
\hline
\end{tabular}

Table.4 Available P (Kg/ha) in Soil under the canopy of A. nilotica at different soil depths

\begin{tabular}{|c|c|c|c|c|c|}
\hline \multirow[t]{2}{*}{ Soil Depth } & \multicolumn{4}{|c|}{ Canopy } & \multirow[t]{2}{*}{ Mean } \\
\hline & $\mathbf{C}_{1}$ & $\mathbf{C}_{2}$ & $\mathbf{C}_{3}$ & $\mathbf{C}_{4}$ & \\
\hline$D_{1}$ & 41.67 & 39.83 & 37.5 & 35.33 & 38.58 \\
\hline $\mathbf{D}_{2}$ & 40.07 & 39.17 & 36.67 & 34.66 & 37.64 \\
\hline $\mathbf{D}_{\mathbf{3}}$ & 38.53 & 38.16 & 35.5 & 34.5 & 36.67 \\
\hline Mean & 40.09 & 39.05 & 36.56 & 34.83 & \\
\hline C.D. ${ }_{5 \%}$ & $\mathrm{C}=$ & $\mathbf{D}=$ & $C * D=$ & & \\
\hline
\end{tabular}

Table.5 Available K (Kg/Ha) in Soil under the canopy of A. nilotica at different soil depth

\begin{tabular}{|c|c|c|c|c|c|}
\hline \multirow{2}{*}{ Canopy } & \multicolumn{4}{|c|}{ Soil Depth } & Mean \\
\cline { 2 - 5 } & $\mathbf{C}_{\mathbf{1}}$ & $\mathbf{C}_{\mathbf{2}}$ & $\mathbf{C}_{\mathbf{3}}$ & $\mathbf{C}_{\mathbf{4}}$ & \\
\hline $\mathbf{D}_{\mathbf{1}}$ & 286.33 & 280.66 & 275 & 272.67 & $\mathbf{2 7 8 . 6 6}$ \\
\hline $\mathbf{D}_{\mathbf{2}}$ & 283.67 & 279.66 & 273.67 & 269.33 & $\mathbf{2 7 6 . 5 8}$ \\
\hline $\mathbf{D}_{\mathbf{3}}$ & 281.32 & 278 & 272.33 & 268.66 & $\mathbf{2 7 5 . 0 8}$ \\
\hline Mean & $\mathbf{2 8 3 . 7 7}$ & $\mathbf{2 7 9 . 4 4}$ & $\mathbf{2 7 3 . 6 7}$ & $\mathbf{2 7 0 . 2 2}$ & \\
\hline C.D. $(\mathbf{5} \%)$ & $\mathbf{C}=$ & $\mathbf{D}=$ & $\mathbf{C} * \mathbf{D}=$ & & \\
\hline
\end{tabular}

The data presented in (Table 3) indicates that irrespective of a canopy of $A$. nilotica the highest value $(0.044 \%)$ of mean total nitrogen in soil was observed at $\mathrm{D}_{1}$ canopy. While irrespective of soil depth, the mean total nitrogen in soil was found highest with the value of $0.048 \%$ at $\mathrm{C}_{1}$ canopy as compared to total nitrogen percent at other soil depths. Across the canopy, the mean total nitrogen in soil decreased with increasing distance of the canopy. However, the highest value of total nitrogen in the soil $(0.058 \%)$ was recorded under tree canopy at $\mathrm{D}_{1}$ soil depth and $\mathrm{C}_{1}$ canopy while the percentage of total nitrogen in soil at $\mathrm{D}_{3}$ soil depth under $\mathrm{C}_{4}$ canopy was found lowest (0.031 \%). Significant variation was found in total nitrogen $\%$ in soil under its canopy at different soil depths.

The maximum value of nitrogen content in soil under tree canopy may be attributed primarily to its restitution to the soil through litter fall (Parthiban \& Rai, 1994). Higher stem flow and root decay might be one of the reasons for the enrichment of soil in total nitrogen under tree canopy (Young, 1997). These observations are in conformity with the experimental findings of Pandey et al., 2000 for A. nilotica; 
It was observed from the data in table 4, that irrespective of soil depth, the highest (40.09 $\mathrm{kg} / \mathrm{ha}$ ) value of mean available phosphorus in soil under $A$. nilotica was recorded at $\mathrm{C}_{1}$ canopy. Whereas, mean available soil phosphorus was found decreasing with increasing distance of tree canopy. Under tree canopy, the mean available soil phosphorus was highest $(38.58 \mathrm{~kg} / \mathrm{ha})$ at D1 soil depth. However available phosphorus decreased with increases in soil depth. However, the maximum value $(41.67 \mathrm{~kg} / \mathrm{ha})$ of available soil phosphorus was recorded under tree canopy at D1 soil depth and C1 canopy radius, while the available soil phosphorus at D3 soil depth under C4 canopy was recorded minimum $(34.50 \mathrm{~kg} / \mathrm{ha})$. Higher availability of phosphorus in soil under tree canopy might be due to the addition of phosphorus through litter formation and sloughing of tree roots. Tree induced increase in available phosphorus was also reported by Singh et al., (2004).

The observation recorded in (Table 5) indicates that under the canopy of A. nilotica, irrespective of soil depth, the highest value $(283.77 \mathrm{~kg} / \mathrm{ha})$ of mean available soil potassium was recorded at $\mathrm{C}_{1}$ canopy. Irrespective of tree canopy, the mean available soil potassium at $\mathrm{D}_{1}$ soil depth was found highest (278.66 kg/ha) in comparison to $\mathrm{D}_{2}$ and $\mathrm{D}_{3}$ soil depth. The mean available soil potassium decreased with increases in soil depth. However, the highest value (286.33 $\mathrm{kg} / \mathrm{ha}$ ) of available soil potassium was found under tree canopy at $\mathrm{D}_{1}$ soil depth and $\mathrm{C}_{1}$ canopy radius While the value of available soil potassium at $\mathrm{D}_{3}$ soil depth under $\mathrm{C}_{4}$ canopy of this tree was found lowest (268.66). Significantly affect the availability of potassium in soil. The increase in available $\mathrm{K}$ in soil may also be ascribed to litter fall. These findings are in close conformation with experimental findings of Parthiban \& Rai, 1994 who studied the effect of trees on soil fertility. Tree induce an increase in the availability of potassium in soil was also reported by Singh et al., (2004).

\section{References}

Erickson, H., Davidson, E. A. and Keller, M., (2002). Former land-use and tree species affect nitrogen oxide emissions from a tropical dry forest. Oecologia, 2002, 130, 297- 308.

Jackson, M.L. (1971) Soil chemical Analysis. Prentice Hall of India Pvt. Ltd., New Delhi.

McGrath, D. A., Duryea, M. L., Comerford, N. B. and Cropper, W. P., (2000). Nitrogen and phosphorus cycling in an Amazonian agroforest eight years following forest conversion. Ecol. Appl., 10, 1633-1647.

Meston, A.J. (1956). Methods of soil chemical analysis for soil survey samples. Bull. N.Z. Dept. Sci. Nat. Res. Soil Sur. Pp. 12.

Olsen,S.R.; Cole, R.V.; Watanabe, F.S. and Lean, L.A. (1954) Estimation of available phosphorus in soil by extraction with sodium bicarbonate. Circ. USDA No. 939.

Parthiban, K.T. and Rai, R.S.V. (1994).Trees on farmlands -their effects on soil fertility. Annals of Forestry 2(1): 44-51.

Richards, L.A. (1954) Diagnosis and improvement of saline and alkali soils. USDA Handbook No.-60.

Richards, L.A. (1954) Diagnosis and improvement of saline and alkali soils. USDA Handbook No.-60.

Rosegrant, M. W. and Cline, S. A. (2003). Global food security: Challenges and policies. Science, 302, 1917-1919.

Rosegrant, M. W. and Cline, S. A., Global food security: Challenges and policies. Science, 2003, 302, 1917-1919.

Sanchez, P. A., (2000). Linking climate change research with food security and poverty reduction in the tropics. Agric. 
Ecosyst. Environ, 82, 371-383.

Sanchez, P. A., Soil fertility and hunger in Africa. Science, 2002, 295, 2019-2020

Schortemeyer, M., Atkin, O. K., McFarlane, N. and Evans, J. R., (2002). N2 fixation by Acacia species increases under elevated atmospheric CO2. Plant Cell Environ., 25, 567-579

Singh, A.N.; Raghubanshi, A.S. and Singh, J.S. (2004). Impact of native tree plantations on mine spoil in a dry tropical environment. For. Ecol. Mgmt., 187: 49-60.

Singh, A.N.; Raghubanshi, A.S. and singh, J.S. (2004). Impact of native tree plantations on mine spoil in a dry tropical environment. For. Ecol. Mgmt., 187: 49-60.

Stocking, M. A., (2003). Tropical soils and food security: The next 50 years. Science, 302, 1356-1359.

Stocking, M. A., (2003). Tropical soils and food security: The next 50 years. Science, 302, 1356-1359.

Walkley, A. and Black, I.A. (1934). Rapid titration method of organic carbon of soils. Soil Sci, 37: 29-33.

Young A. (1997). Agroforestry for soil management. CAB International, Wallingford, UK and ICRAF, Nairobi, Kenya.

\section{How to cite this article:}

Chatar Singh and Shayma Parveen. 2020. Effect of Canopy of Acacia nilotica on Soil Fertility Status at Varying Soil Depths in Wheat Based Agroforestry System. Int.J.Curr.Microbiol.App.Sci. 9(10): 1980-1988. doi: https://doi.org/10.20546/ijcmas.2020.910.241 